Jurnal Kesehatan Masyarakat

\title{
Family Function and Misuse of Drug in Adolescents in Indonesia
}

\author{
Oktriyanto $^{1 \bowtie}$, Hilma Amrullah ${ }^{1}$, Anastasia Septya Titisari² \\ ${ }^{1}$ Badan Kependudukan dan Keluarga Berencana Nasional (BKKBN), Indonesia \\ ${ }^{2}$ Community Development Program Murdoch University, Western Australia
}

\begin{tabular}{l} 
Article Info \\
\hline Article History: \\
Submitted February 2020 \\
Accepted September 2020 \\
Published November 2020 \\
\hline Keywords: \\
Family function, \\
Adolescents, drugs, \\
cigarette, alcohol \\
\hline DOI \\
https://doi.org/10.15294/ \\
kemas.v16i2.23304
\end{tabular}

\section{Article Info}

Accepted September 2020

Published November 2020

Keywords:

Family function,

Adolescents, drugs,

DOI

kemas.v16i2.23304

\begin{abstract}
In Indonesia drug in adolescents shows a number that tends to be high. This phenomenon is certainly an indication that there are character problems in children and adolescents in Indonesia, which certainly cannot be separated from the role of parents. In this case the function of parents and government support is needed in an effort to handle the use of drugs in teenagers in Indonesia. The results showed that the majority of adolescents who used drugs were more in adolescents who had heads of households with low education and had families with a low wealth index, were in whole families, and more in adolescents who lived in rural areas. Teenage boys tend to use drugs more than girls. Teenagers who use drugs have more characteristics of the 20-24 year age group, low education and are not working. The factors that significantly affect the use of drug use among adolescents include socio-cultural functions, place of residence, adolescence, adolescent sex, work status, adolescent access to PIK-R programs, and knowledge of the impact of drugs.
\end{abstract}

\section{Introduction}

Human resources (HR) are the most important aspects needed to advance a nation. Development carried out by a country will run optimally if it is supported by quality human resources. Quality resources can be seen from several aspects such as physical, intellectual, and psychological / social emotional abilities (Kulla, Rumapea and Tampongangoy, 2018). This quality can also be reflected in the behavior that is carried out on each individual.

According to (BPS, 2018), there has been an increase in criminal behavior, including drug use and abuse. Drug is the use of narcotics, psychotropic substances and other addictive substances. Starting from 2014-2017, there was an increase of 3.17 percent in the percentage of total drug use and abuse that was not only committed by adults but also by children and adolescents. In 2014 alone there were around 4 million drug users in Indonesia (BNN, 2015).
Meanwhile, globally, at least 5.6 percent of the world's population over the age of 15 has consumed drugs (UNODC, 2018).

Adolescents are prone to drug abuse because the socio-emotional conditions of adolescents are not yet stable so they are easily influenced into deviant behavior (Nur'artavia, 2017). Teens also have great curiosity so that they will seek information about drugs, and have the potential to use them, starting with trial and error. Because of this curiosity, adolescents tend to use risky behaviors such as smoking, drinking alcohol, using drugs, and free sex (Azmiyati, 2014; Shaluhiyah et al., 2020). Basically, smoking and drinking alcohol are the gateway to drug abuse (Hanifah and Unayah, 2011; BNN, 2015; Sari, 2019). More specifically, cigarettes are actually included in the definition of a drug. Smoking is now no longer a health problem, but it already has its own complexities. 
The high level of criminal behavior such as drug use and smoking behavior in adolescence shows that there are still many deviant behaviors committed by adolescents in Indonesia. On the other hand, this fact also shows that there is a problem with the character of Indonesian adolescents. Character is one aspect of a person's development that is inseparable from the role of the family, one of which is parents (Rohmah and Athfal, 2018). The family is not only the basic or smallest unit of society, but also an important place for the physical and mental growth of the individual. At the same time, the family influences the growth of each member and plays an important role in the social system (Dai and Wang, 2015). Several research results show that family function affects the quality of life of family members including children and adolescents (Farajzadegan et al., 2013; Herawati and Endah, 2016; Desiningrum, Suminar and Surjaningrum, 2019; Yuan, Zhuo and Li, 2019). Optimization of family functions is expected to be the basis of the family to ensure adolescents are free from risky behavior (Gustiani and Ungsianik, 2016).

\section{Method}

This study was conducted to identify family functions in adolescent families, as well as knowledge and drug abuse in adolescents. The study design was a cross sectional study. This study uses secondary data from the results of the Performance Survey and Accountability for Population Program, Family Planning and Family Development (SKAP) in 2018.

The sampling in this survey was carried out in several stages, namely: Stage 1: Selecting a number of villages by Probability Proportionate to Size (PPS) sampling with the size of the number of households in the list of all villages / wards (or in the sample frame of all villages). The village sample was selected independently between urban and rural areas in a district / city. Stage 2: Selecting one cluster from each selected village by means of PPS sampling with the size of the number of households in the selected cluster. And Stage 3: Selecting 35 households using systematic random sampling based on the results of household listings conducted door to door by enumerators in each selected cluster.

The samples taken in this study were divided into two groups based on the type of questionnaire, namely the family and adolescent questionnaires. From the survey conducted, 69,515 families who met the requirements as respondents for the family questionnaire and were successfully interviewed. Of the 69,515 families that were successfully interviewed, 22,721 unmarried women and men aged 15-24 were identified, then these adolescents became respondents for the youth questionnaire. There were 22,210 adolescents who were successfully interviewed, but the data on adolescents that could be analyzed were only 22,180 data. This is because the other 30 adolescents did not meet the sample criteria, namely the paired data with the family questionnaire data.

The data used in this study is secondary data, which is data from the results of the Population, Family Planning and Family Development Program (KKBPK) Performance Indicator Survey for the 2018 National Middle Development Plan (RPJMN). All measuring instruments / questionnaires in this study were compiled and developed by the BKKBN team. The data used include the age of the head of the family, the education of the head of the family, the wealth index, and the type of family, the place of residence, the teenage age, and the sex of adolescents, the education of adolescents, the work status of adolescents, adolescents' access to the PIK-R program, knowledge and use of drugs.

The family function variable in the SKAP 2018 BKKBN was obtained by asking respondents exploratively, meaning that the answers were obtained from the respondent's expression which was then summarized by the interviewer himself to match the answer choices with the respondent's answer. The function of religion consists of: worship (praying, pray, fasting, mass, etc.), tolerance for other religions, doing good things (helping others), being patient and sincere, others, and not know. The socio-cultural function consists of mutual cooperation, deliberation, preserving regional culture / customs, respecting between ethnic groups / races / religions / groups, others and not know. Love function consists of: loyalty / mutual trust, not favoritism / fairness, maintaining family harmony, showing affection, others, and not know. The protection function consists of: physical protection 
(holding a child / partner, hugging, etc.), nonphysical protection (not saying harshly), health protection, meeting family needs (clothing, food, and shelter), others, and not knowing. The reproductive function consists of: maintain cleanliness of body organs, provide reproductive health information, avoid promiscuity, marry off children at ideal ages, others, and not know. The functions of socialization and education consist of being a role model or example, sending children to school, teaching children to be independent, responsible and able to work together, training children's creativity, others and not know. The economic function of the answer choices consists of being frugal (not wasteful), resilient / hard working, able to save, being able to choose needs according to priority, others and not know. Environmental functions consist of: not littering, cleaning the surrounding environment, preserving the environment (afforestation), saving energy, etc. and not know.

Data processing carried out in this study includes the variables selected from the questionnaire as well as exploring the data in accordance with the research objectives. The first step is to check the data, clean the data, or delete data that are outside the analysis. Then recode the selected variables in accordance with the operational definition and questionnaire. After that, the calculation (scoring), composite or data combination of various variables in the questionnaire is carried out and categorize them according to the operational definition of the research. The final step is data analysis in accordance with the research objectives. Data analysis was performed using the SPSS version 15.0 program. Data analysis was carried out descriptively and inference (multiple logistic regression test). Multiple logistic regression tests were used to analyze the factors that influence drug abuse among adolescents in Indonesia.

The limitations of this analysis include the absence of a time frame in the drug use variable. There are several important factors that may be related to drug abuse among adolescents such as the main activity of adolescents during the survey (school student, not school student), smoking behavior, and peer influence. Data are also not available in this analysis.

\section{Results and Discussion}

The analysis found that there were more teenage families living in urban areas (55\%). The education of parents, in this case is the education of the head of the family, shows that 64 percent are in the low category, from not going to school to completing junior high school, and most (89\%) are in the middle-late age group ( $>40$ years). Meanwhile, the family wealth index shows a greater percentage in the low category, namely 56 percent.

Adolescents generally live in intact families $(89 \%)$ or are in families with fathers and mothers. As for the characteristics of adolescents, it is known that the largest percentage of adolescents (67\%) is in the 15-19 age group. Meanwhile, based on gender, male adolescents were more numerous than girls, namely 56 percent. 74 percent of adolescent education is in higher education (high school university) and most of them have not worked (76\%).

The family as a producer of human resources (HR) must carry out its functions properly in order to produce quality human resources. Government Regulation of the Republic of Indonesia number 87 of 2014 divides family functions into eight functions, namely functions of religion, socio-culture, love, protection, reproduction, socialization and education, economy, and environmental development. The function of the family must be the foundation and guidance of every family in order to create a prosperous and quality family. Family malfunctions such as in economic terms and the absence of protection in the family can cause negative behavior in children, especially adolescents (Putri, 2018).

The index value of family functions in this survey is in the range of $0-100$ and is divided into two categories low (index value less than 50) and high (index value greater than or equal to 50). Based on the results of the analysis, the index values in each family function are: religious function (46), socio-culture (45), love (50), protection (46), reproduction (43), socialization and education (44), economics (54), and environmental development (44). This shows that the most dominant implementation of family functions is seen in the economic function and love. The economic function is 
Table 1. Percentage of index value for implementation of eight (8) family functions, Indonesia $2018(\mathrm{~N}=22,180)$

\begin{tabular}{lll}
\hline Application of the Eight (8) Functions of the Family & \multicolumn{2}{l}{ Family function index category } \\
\cline { 2 - 3 } & $\begin{array}{l}\text { Low } \\
\text { (index }<50)\end{array}$ & $\begin{array}{l}\text { High } \\
\text { (index }>50)\end{array}$ \\
\hline Function of Religion & 60.1 & 39.9 \\
Socio-Cultural Functions & 63.2 & 36.8 \\
Love Function & 53.3 & 46.7 \\
Protection Function & 60.8 & 39.2 \\
Reproductive Function & 65.3 & 34.7 \\
Education Socialization Function & 64.3 & 35.7 \\
Economic Functions & 43.5 & 56.5 \\
Environmental Functions & 64.7 & 35.3 \\
Total of Eight (8) Family Functions & 59.4 & 40.6 \\
\hline
\end{tabular}

Source: SKAP 2018 - Combining family data with adolescent data

considered the most vital function to carry out other functions.

Religion is a basic need of every human being. Family is the first place to instill religious values and give religious identity to every child born. The family fosters religious values, so that children become human beings with good character and piety. The family teaches all its members to carry out worship with full faith and devotion to God Almighty. Carrying out religious functions must not neglect religious tolerance because Indonesian families adhere to various beliefs and religions (BKKBN, 2017). The results of the analysis show that, the function of religion that is most widely applied in the family is carrying out worship such as: prayer, fasting, reciting the Qor'an, praying, mass, etc. (97\%), doing good / helping others (55\%), while religious values others less than 50 percent.

The family is the main vehicle for fostering and cultivating noble cultural values that have been role models in the system of life. The socio-cultural function provides opportunities for families and all members to develop the nation's diverse cultural wealth in one unit. The family is the first vehicle for children to learn to interact and adapt to the surrounding environment as well as learn the customs that apply around them (BKKBN, 2017). The results of the analysis show that the socio-cultural functions that are most widely applied in the family are carrying out mutual cooperation (64\%), preserving regional culture / customs (50\%), while other socio-cultural values are less than 50 percent.

Love and affection are important components in shaping children's character. The function of love means that the family must be a place to create an atmosphere of love and affection in family, community, national and state life. The function of love can be manifested in the form of providing affection and security, as well as giving attention to family members (BKKBN, 2017). The results of the analysis show that the function of love that is most widely applied in the family is showing affection $(72 \%)$, maintaining harmony (62\%), not favoritism / being fair to each family member (50\%), while other values of love with a percentage of less than 50 percent.

The family is a place of shelter or refuge for all its members, and a place to cultivate a sense of security and warmth. With an atmosphere of mutual protection, the family must be a safe, comfortable and reassuring place for all its members. If the family functions properly, the family will be able to provide a protective function for its members and can optimize children's growth and development. The family protects every member from bad actions, so that family members feel comfortable and protected from unpleasant things (BKKBN, 2017). The results of the analysis show that 
the most common protection functions in the family are non-physical protection such as not saying harsh words (55\%), health protection (55\%), meeting the basic needs of the family (clothing, food and shelter) by 54 percent, physical protection such as holding, hugging, etc. $(50 \%)$ while the value of other protection is less than 20 percent.

The family controls the reproduction of offspring in a healthy and planned manner, so that the children who are born become qualified future generations. The family is places to develop overall reproductive function including healthy and quality sexuality, and sexuality education for children. The family is also a place to provide information to its members about matters related to sexuality. Continuing the planned descent can support the creation of family welfare (BKKBN, 2017). The results of the analysis show that the reproductive function that is mostly applied in the family is avoiding promiscuity (73\%), maintaining the cleanliness of the reproductive organs (54\%), while other reproductive values are with a percentage of less than 50 percent..

Family is as the main and first place to provide education to all children for future provisions. The education provided by the family includes education to educate and shape children's character. Socialization and education functions also mean that the family is a place to develop interaction processes and a place to learn to socialize and communicate well and healthily. The interaction is very intensive in the family so the educational process runs very effectively. Families socialize to their children about values, norms, and ways to communicate with others, teach about good and bad things as well as wrong and right things (BKKBN, 2017). The results of the analysis show that the socialization and education functions that are most widely applied in the family are sending children to school or educating children (91\%), teaching children to be independent, responsible and able to work together (53\%), while the value of socialization and other education is less than 50 percent.

The family is the main place in fostering and instilling values related to finance and managing the use of finances to meet the needs of life and create a prosperous family. Family as a place to obtain food, clothing, shelter, and other material needs as well as provides financial support to its members (BKKBN, 2017). The results of the analysis show that the economic functions that are most widely applied in the family are saving (93\%), saving or not being wasteful in using money (75\%), buying goods according to priority needs (50\%) while other economic values with a percentage of less than $50 \%$. percent.

The family has the role of managing life while maintaining the surrounding environment, both physical and social, and the micro, meso, and macro environment. The family plays a role in fostering the community and natural environment. Families and their members must know their neighbors and the community around them and care for the preservation of the natural environment. The family's caring attitude towards the environment is to provide the best for future generations (BKKBN, 2017). The results of the analysis show that the environmental functions that are most widely applied in the family are cleaning the surrounding environment (86\%), not littering (72\%) while other environmental values are with a percentage of less than 50 percent.

All adolescent respondents, both women and men were asked whether they had ever heard of the term NAPZA. Almost all adolescents (97 percent) have heard of drugs. From what they have heard, adolescents are asked about the impact of drug use. The knowledge index score on the impact of drug use was divided into two categories low (index value less than 50 ) and high (index value greater than or equal to 50) from the index interval 0-100. Overall, the knowledge index value on the impact of drug use from each dimension was in the low category, namely the physical impact index value of 26 , the psychological impact of 25 , the socio-economic impact of 20 and the total knowledge index of the impact of drug use was 24.

In general, female adolescents are better informed about the impact of drug use than young men. The results of the analysis showed that the knowledge index of drug use in adolescent girls was 26, while male adolescents were 23. Based on the knowledge 
Table 2. Percentage of adolescents by gender and knowledge index on the impact of drug use, Indonesia 2018

\begin{tabular}{|c|c|c|c|c|c|c|c|}
\hline \multirow{3}{*}{$\begin{array}{l}\text { Knowledge Index on the } \\
\text { Impact of Drug Use }\end{array}$} & \multicolumn{6}{|c|}{ Gender } & \multirow{3}{*}{$\mathrm{P}$-value } \\
\hline & \multicolumn{2}{|c|}{$\begin{array}{l}\text { Female } \\
(\mathrm{N}=12.415)\end{array}$} & \multicolumn{2}{|c|}{$\begin{array}{l}\text { Male } \\
(\mathrm{N}=9.766)\end{array}$} & \multicolumn{2}{|c|}{$\begin{array}{l}\text { Total } \\
(\mathrm{N}=22.180)\end{array}$} & \\
\hline & $\mathrm{N}$ & $\%$ & $\mathrm{~N}$ & $\%$ & $\mathrm{~N}$ & $\%$ & \\
\hline \multicolumn{8}{|l|}{ Physical Impact (A) } \\
\hline Low (index < 50) & 8.900 & 91.1 & 11.573 & 93.2 & 20.473 & $9 ., 3$ & 0.000 \\
\hline Height (index >50) & 865 & 8.9 & 842 & 6.8 & 1.707 & 7.7 & \\
\hline \multicolumn{8}{|l|}{ Psychological Impact (B) } \\
\hline Low (index $<50$ ) & 8.476 & 86.8 & 11.036 & 88.9 & 19.512 & 88.0 & 0.000 \\
\hline High (index > 50) & 1.289 & 13.2 & 1.378 & 11.1 & 2.668 & 12.0 & \\
\hline \multicolumn{8}{|l|}{ Socio-Economic (C) } \\
\hline Low (index $<50$ ) & 7.806 & 79.9 & 10.439 & 84.1 & 18.245 & 82.3 & 0,000 \\
\hline High (index $>50$ ) & 1.960 & 20.1 & 1.975 & 15.9 & 3.935 & 17.7 & \\
\hline \multicolumn{8}{|l|}{$\operatorname{Impact}(\mathrm{A}+\mathrm{B}+\mathrm{C})$} \\
\hline Low $($ index $<50)$ & 8.583 & 87.9 & 11.315 & 91.1 & 19.897 & 89.7 & 0,000 \\
\hline High (index $>50$ ) & 1.183 & 12.1 & 1.100 & 8.9 & 2.283 & 10.3 & \\
\hline
\end{tabular}

Source: SKAP 2018 - Combining family data with adolescent data

index category on the impact of drug use (Table 2 ), the percentage of knowledge on the physical impact of drug use was the lowest in the high index category. ( $>50)$ that is, with a percentage of 8 percent. Meanwhile, the psychological and socio-economic impacts that fall into the high category are 12 percent and 18 percent, respectively.

Adolescents who have heard of drugs are asked whether or not they have consumed drugs. The results of the analysis show that teenagers in Indonesia consume 8 percent of drugs, where male adolescents consume more drugs than female adolescents, namely 11 percent and 4 percent, respectively. Table 3 shows the percentage of adolescents according to family function and has ever consumed drugs. The statement of family function taken is a function item of each family function that is related to or can explain the use of drugs among adolescents. Religious functions are approached by families carrying out worship according to their religion or belief, sociocultural functions, love functions, protection functions, reproductive functions, socialization $\&$ education functions, and economic functions. Meanwhile, the environmental function is not included in analyzing drug use because the answer options for environmental functions are limited to the physical environment, such as not littering, cleaning the surrounding environment, preserving the environment (reforestation), saving energy, and others. Almost all adolescents who have ever consumed drugs mostly carry out various family functions, namely carrying out religious, socio-cultural, love, protection, reproduction, and economic functions. Meanwhile, the family carries out the socialization and education function with the same percentage for adolescents who consume or do not consume drugs.

According to (Çiftçi Demirci et al., 2015) the use of drugs in adolescents can be influenced by individual characteristics and family background factors. Based on the characteristics of the family background, adolescents who have consumed drugs in the age group of family heads $<40$ years with $>40$ years have no difference, namely 7.7 percent. Next. adolescents who have consumed the most drugs in families with low education of the head of the family (8\%), low wealth index (8\%), the type of whole family (8\%), and living in the village (9\%). This result is in line with research (Nasution et al., 2019) which found that adolescents who have families with low wealth quintiles tend to be more prone to consuming drugs. Other factors such as age and gender can 
Table 3. Percentage of adolescents according to family function and having consumed drugs, Indonesia $2018(\mathrm{~N}=22180)$

\begin{tabular}{|c|c|c|c|c|}
\hline \multirow[t]{2}{*}{ Family function } & \multicolumn{2}{|c|}{ Drug Consumption } & \multirow[t]{2}{*}{$\mathrm{N}$} & \multirow[t]{2}{*}{ P-Value } \\
\hline & Ever & Never & & \\
\hline \multicolumn{5}{|l|}{ Religious Functions } \\
\hline No & 5.2 & 94.8 & 310 & 0.093 \\
\hline Yes & 7.7 & 92.3 & 21.869 & \\
\hline \multicolumn{5}{|l|}{ Socio-Cultural Functions } \\
\hline No & 7.2 & 92.8 & 12.205 & 0.003 \\
\hline Yes & 8.3 & 91.7 & 9.974 & \\
\hline \multicolumn{5}{|l|}{ Love Function } \\
\hline No & 7.4 & 92.6 & 6.197 & 0.387 \\
\hline Yes & 7.8 & 92.2 & 15.982 & \\
\hline \multicolumn{5}{|l|}{ Protection Function } \\
\hline No & 7.1 & 92.9 & 9.945 & 0.002 \\
\hline Yes & 8.2 & 91.8 & 12.235 & \\
\hline \multicolumn{5}{|l|}{ Reproductive Function } \\
\hline No & 7.2 & 92.8 & 6025 & 0.124 \\
\hline Yes & 7.9 & 92.1 & 16155 & \\
\hline \multicolumn{5}{|c|}{ Socialization \& Education Function } \\
\hline No & 8.4 & 91.6 & 1.978 & 0.220 \\
\hline Yes & 7.6 & 92.4 & 20.202 & \\
\hline \multicolumn{5}{|l|}{ Economic Functions } \\
\hline No & 6.9 & 93.1 & 1462 & 0.274 \\
\hline Yes & 7.7 & 92.3 & 20718 & \\
\hline
\end{tabular}

Source: SKAP 2018 - Combining family data with adolescent data

also contribute to the tendency for adolescents to use drugs. This research proves that based on the characteristics of adolescents, adolescents who have consumed the most drugs are in the characteristics of adolescents in the 20-24 year age group (10\%), male adolescents (11\%), low education (9\%), work status (11\%), access to the PIK R program (9\%) and have high knowledge of the impact of drug use (10\%).

Another interesting finding in this study shows that both adolescents who still have intact parents (mother and father) and adolescents who only have single parents (father or mother only) do not have a significant difference in drug abuse (the percentage is almost the same). This is likely the relationship satisfaction factor between adolescents and parents, not because the factor of adolescence is in a complete or incomplete family. Teens who are dissatisfied with their relationship with their father and mother tend to abuse drugs (Freitas and Souza,
2020).

BKKBN in accordance with the mandate of Law Number 52 of 2009 is to develop the Planning Generation Program. The Planning Generation Program is a program developed in the context of preparing family life for adolescents so that they are able to carry out a planned education level, have a career in a planned job, and marry in full planning according to the reproductive health cycle. The GenRe program is aimed at adolescents through the Youth Information and Counseling Center (PIK-R) and families who have teenagers through the Youth Family Development forum.

PIK Remaja is one of the platforms developed in the GenRe program. which is managed by and for adolescents in order to provide information and counseling services on maturity of marriage age, eight family functions, TRIAD KRR (sexuality, HIV-AIDS and drugs), and life skills. The existence and 
Table 4. Percentage of adolescents according to background characteristics and having consumed drugs, Indonesia $2018(\mathrm{~N}=22,180)$.

\begin{tabular}{|c|c|c|c|c|}
\hline \multirow{2}{*}{ Background Characteristics } & \multicolumn{2}{|c|}{ Use of drugs } & \multirow{2}{*}{$\mathrm{N}$} & \multirow{2}{*}{ P-Value } \\
\hline & Ever & Never & & \\
\hline \multicolumn{5}{|l|}{ Family Characteristics } \\
\hline \multicolumn{5}{|l|}{ Age of Family Head } \\
\hline$<40$ years & 7.7 & 92.3 & 2.542 & 0.907 \\
\hline$>40$ years & 7.7 & 92.3 & 19.683 & \\
\hline \multicolumn{5}{|l|}{ Education of Family Head } \\
\hline Low & 8.1 & 91.9 & 14.122 & 0.002 \\
\hline High & 6.9 & 93.1 & 8.058 & \\
\hline \multicolumn{5}{|l|}{ Wealth Index } \\
\hline Low & 8.2 & 91.8 & 12.331 & 0.002 \\
\hline High & 7.1 & 92.9 & 9.850 & \\
\hline \multicolumn{5}{|l|}{ Family Type } \\
\hline Incomplete & 7.5 & 92.5 & 2.431 & 0.748 \\
\hline Complete & 7.7 & 92.3 & 19.749 & \\
\hline \multicolumn{5}{|l|}{ Residence Location } \\
\hline Village & 8.5 & 91.5 & 9.997 & 0.000 \\
\hline City & 7.0 & 93.0 & 12.210 & \\
\hline \multicolumn{5}{|l|}{ Characteristics of Adolescents } \\
\hline \multicolumn{5}{|l|}{ Age } \\
\hline $15-19$ years & 6.6 & 93.4 & 14.873 & 0.000 \\
\hline 20-24 years & 9.9 & 90.1 & 7.307 & \\
\hline \multicolumn{5}{|l|}{ Gender } \\
\hline Female & 3.7 & 96.3 & 9.765 & 0.000 \\
\hline Male & 10.8 & 89.2 & 12.414 & \\
\hline \multicolumn{5}{|l|}{ Education } \\
\hline Low & 8.6 & 91.4 & 5.717 & 0.002 \\
\hline High & 7.4 & 92.6 & 16.464 & \\
\hline \multicolumn{5}{|l|}{ Working Status } \\
\hline Not working & 6.6 & 93.4 & 16.750 & 0.000 \\
\hline Working & 11.2 & 88.8 & 5.431 & \\
\hline \multicolumn{5}{|l|}{ Access the PIK-R Program } \\
\hline Never & 7.6 & 92.4 & 20.288 & 0.042 \\
\hline Ever & 8.9 & 91.1 & 1.892 & \\
\hline \multicolumn{5}{|l|}{ Knowledge of the impact of drugs } \\
\hline Low & 7.4 & 92.6 & 19.898 & 0.000 \\
\hline High & 10.4 & 89.6 & 2.283 & \\
\hline
\end{tabular}

Source: SKAP 2018 - Combining family data with adolescent data

role of PIK-R in the youth environment is very important in helping adolescents to obtain sufficient and correct information and counseling services about the preparation of family life for adolescents.

Adolescents who access the PIK-R
Program are expected to avoid risky behavior such as drug abuse. Teens who take PIK-R will be exposed to materials related to drugs, such as the types of drugs and the impact of drug use. The results of the analysis show that only nine out of one hundred adolescents in Indonesia 
access the PIK-R Program, with details of which six percent access via online (internet) / social media and through participating in group activities (POKTAN) - PIK R is five percent. The results of the Chi-Square test showed that adolescents who had access to the PIK R program had a statistically significant effect on adolescents' knowledge of the impact of drug use $(\alpha=0.000)$. Similar results were also found in research (Sholihah, 2015), after counseling was carried out on the prevention and abuse of drugs, there was an increase in knowledge about the definition, type and content, and the impact of drug abuse.

Drug abuse is a significant problem among adolescents in many countries, this is indicated by its high prevalence (Mametja and Ross, 2020; Patterson et al., 2020). Adolescence is a period that is very vulnerable to risky behavior, including in the case of drug abuse, this is due to high curiosity accompanied by unstable behavior both socially and emotionally. Factors affecting drug abuse among adolescents in this article were analyzed using logistic regression tests. The independent variables used were family functions (religious, socio-cultural, love, protection, reproduction, socialization \& education, and economic functions), family characteristics (age of the head of the family, education of the head of the family, wealth index, type of family, location. place of residence), the characteristics of adolescents (adolescent age, gender, education, work status, access to the PIK-R program, knowledge of the impact of drug use) with the dependent variable is the use of drugs among adolescents. The results of the regression test showed that the variables that were significantly related to the use of drugs among adolescents consisted of sociocultural functions, location of residence, age of adolescents, gender of adolescents, adolescent work status, access to the PIK R program, and knowledge of the impact of drugs.

The active involvement of parents in developing skills, social competence, selfregulation and caring for adolescents is important in preventing adolescents from behaving negatively (Das et al., 2016). The results of the study (Asmoro and Melaniani, 2016) show that parents who are too busy and do not instill values and norms in children have a significant effect on drug abuse among adolescents. There is a relationship between drug use in adolescents and unhealthy family functions (Bradshaw et al., 2016). The analysis showed that of the 7 family functions tested only the socio-cultural function had a significant effect. Families who carry out socio-cultural functions tend to have their teenage children consume drugs. This is possible even though the adolescents in the family are socially good, but there are other factors outside the family that affect adolescents using drugs, such as the influence of peers or a negative environment. (Indrawati and Rahimi, 2019) prove that drug use in adolescents can be significantly affected by family function and adolescent self-control factors.

The rules in the family regarding the inculcation of principles and character that are inconsistently taught in divorced families make adolescents disobey the existing rules in the family (Kusumastuti and Hadjam, 2017). According to (Nagarkoti, ShakuntlaPunia and Poonam, 2014), the family plays an important role in building and providing a basis for protection for the mental development of adolescents. Adolescents who are in a harmonious family environment and apply effective communication are shown to have a lower tendency to use drugs (Shin, MillerDay and Hecht, 2019). The results of research (Mak, Leung and Loke, 2019) conducted on adolescents in Hong Kong found that the attachment between children and parents resulted in self-confidence for children so that it was not easy to fall into drug abuse.

The location of residence in this study has a significant effect on drug abuse. This is not in line with research (Patterson et al., 2020), that adolescents living in rural areas tend to be more likely to abuse drugs than adolescents who live in urban areas. These findings indicate that drug abuse does not only occur in big cities but has entered rural areas which can be caused by access to information from the internet.

Adolescent age has a significant effect on drug abuse among adolescents. Adolescents in the age group of more than or equal to 20 years are more likely to abuse drugs than adolescents in the younger age group $(<20$ years). Adolescents are prone to drug abuse 
Table 5 Logistic Regression Coefficient Factors Affecting Drug Abuse among Adolescents

\begin{tabular}{|c|c|c|c|}
\hline \multirow{2}{*}{ Variable } & \multicolumn{3}{|c|}{ Coefficient } \\
\hline & B & $\operatorname{Exp}(B)$ & Sig. \\
\hline \multicolumn{4}{|l|}{ Family Functions } \\
\hline Religious function $(0=$ no. $1=$ yes $)$ & 0.386 & 1.472 & 0.140 \\
\hline Socio-cultural function $(0=$ no. $1=$ yes $)$ & 0.137 & 1.146 & $0.014^{\star}$ \\
\hline The love function $(0=$ no. $1=$ yes $)$ & -0.038 & 0.962 & 0.525 \\
\hline Protection function $(0=$ no. $1=$ yes $)$ & 0.076 & 1.079 & 0.173 \\
\hline Reproduction function $(0=$ no. $1=$ yes $)$ & 0.043 & 1.044 & 0.491 \\
\hline Socialization and education functions $(0=$ no. $1=$ yes $)$ & -0.136 & 0.873 & 0.127 \\
\hline Economic functions $(0=$ no. $1=$ yes $)$ & 0.114 & 1.121 & 0.300 \\
\hline \multicolumn{4}{|l|}{ Family Characteristics } \\
\hline Age of family head ( $0=<40$ years. $1=>40$ years $)$ & -0.107 & 0.899 & 0.188 \\
\hline Education of family head $(0=$ low. $1=$ high $)$ & -0.010 & 0.991 & 0.874 \\
\hline Wealth Index $(0=$ low. $1=$ high $)$ & -0.083 & 0.920 & 0.152 \\
\hline Family type $(0=$ incomplete. $1=$ complete $)$ & 0.128 & 1.137 & 0.126 \\
\hline Residence location $(0=$ village. $1=$ city $)$ & -0.170 & 0.844 & $0.002^{*}$ \\
\hline \multicolumn{4}{|l|}{ characteristics of Adolescents } \\
\hline Age $(0=<20$ years. $1=>20$ years $)$ & 0.212 & 1.236 & $0.000^{\star *}$ \\
\hline Gender $(0=$ female. $1=$ male $)$ & 1.120 & 3.066 & $0.000^{* *}$ \\
\hline Education $(0=$ low. $1=$ high $)$ & 0.011 & 1.011 & 0.855 \\
\hline Work status $(0=$ not working 1 = working $)$ & 0.402 & 1.495 & $0.000^{* *}$ \\
\hline Access the PIK-R program $(0=$ no. $1=$ yes $)$ & 0.401 & 1.494 & $0.000^{* *}$ \\
\hline Knowledge of the effects of drugs $(0=$ low. $1=$ high $)$ & 0.373 & 1.452 & $0.000^{* *}$ \\
\hline
\end{tabular}

Description: ${ }^{\star}$ significant at $\mathrm{P}<0.05 .{ }^{* \star}$ Significant at $\mathrm{p}<0.001$

Source: SKAP 2018 - Combining family data with adolescent data

because their emotional and mental levels are still very unstable, so they are easily influenced into deviant behavior. This can be due to several things, including a very large curiosity, imitating the behavior of friends, a strong sense of group solidarity to the lack of attention to family factors (Nur'artavia, 2017).

Gender has a significant effect on drug abuse among adolescents. Boys are more likely to abuse drugs than girls. The behavior of male adolescents is more susceptible to consuming drugs than female adolescents. It is possible that male adolescents smoke more than female adolescents, because smoking is one of the main gates for adolescents in drug abuse. (Astuti and Hastono, 2020) also found that compared to women, more male adolescents were committing drug abuse accompanied by smoking behavior since childhood. Not only smoking, men are also more at risk of becoming alcoholics and using illegal drugs (Khan et al., 2014; Ansari-Moghaddam et al., 2016; Oroian, Nemeș and Cozman, 2018). Furthermore, based on work status, adolescents with working status have a greater risk of using drugs. One reason is that working youth can more easily obtain drugs because they already have their own income.

The PIK-R program is one of the government programs, in this case the BKKBN (National Population and Family Planning Board) which calls on adolescents to avoid drugs. Due to the popularity of adolescents with the PIK-R program both through online media and direct participation in group activities, it is hoped that teenagers can avoid drugs. However, the results of this analysis indicate that adolescents who have access to 
the PIK-R Program are more likely to use drugs than those who do not. Some possibilities that occur are that adolescents who access the PIK-R program are those who have already consumed drugs, second are the possibility of trial and error behavior that previously did not know about drugs after participating in the PIK-R program became exposed to drugs so they were interested in trying them. A person who has good knowledge about drugs does not necessarily show a high resistance to drug use. The results of this study are not different from the research conducted by (Mametja and Ross, 2020), the results of their research show that adolescents who use drugs have a fairly good understanding of the impact of drug use. Another possibility is peer influence (Griffith and Jackman, 2019), by participating in the PIK-R program, adolescents meet friends of the same age and may have used and influenced other teenagers. Thus there needs to be control from older people in every activity that is followed by adolescents.

\section{Conclusion}

In this study, it is known that the family functions that are mostly applied by families with adolescent children are the economic function and the function of love, while only the socio-cultural function that affects drug abuse. Of all adolescents who were respondents in this study, it is known that almost all of them know or have heard of drugs. However, adolescents' knowledge of the impact of drug use is still in a low category. As for all adolescents who know about drugs, it is known that only eight percent have ever consumed drugs.

One of the factors that can significantly influence the use of drugs in adolescents is age, gender, work status, and place of residence. In this study it was also found that the PIK-R program is one of the factors that influence drug abuse among adolescents. This finding is a fact that adolescents who consume drugs basically already know the effects of using drugs. Therefore, to be able to prevent drug abuse among adolescents, it takes more than just adolescent knowledge of the dangers and negative effects of consuming drugs. It takes the role of the family in providing education, supervision, and creating a healthy environment and relationships in the family.

\section{References}

Ansari-Moghaddam, A. et al. (2016) 'Prevalence and patterns of tobacco, alcohol, and drug use among Iranian adolescents: A metaanalysis of 58 studies', Children and Youth Services Review, 60, pp. 68-79. doi: https:// doi.org/10.1016/j.childyouth.2015.11.018.

Asmoro, D. O. S. and Melaniani, S. (2016) 'Pengaruh Lingkungan Keluarga terhadap Penyalahgunaan NAPZA pada Remaja, Jurnal Biometrika dan Kependudukan, 5(1), pp. 80-87. doi: 10.20473/jbk.v5i1.2016.8087.

Astuti, N. H. and Hastono, S. P. (2020) 'Is the Frequency of Smoking Affecting the Risk of Abusing Cannabis?', KEMAS: Jurnal Kesehatan Masyarakat, 16(1), pp. 44-52. doi: 10.15294/kemas.v16i1.18063.

Azmiyati, S. (2014) 'Gambaran Penggunaan Napza Pada Anak Jalanan Di Kota Semarang, KEMAS: Jurnal Kesehatan Masyarakat, 9(2), pp. 137-143. doi: 10.15294/kemas.v9i2.2841.

BKKBN (2017) Penanaman dan Penerapan Nilai Karakter Melalui 8 Fungsi Keluarga. BKKBN. Jakarta.

BNN (2015) Laporan Akhir Survei Perkembangan Penyalahgunaan Narkoba di Indonesia Tahun Anggaran 2014. Jakarta: Puslitdatin BNN.

BPS (2018) Statistik Kriminalitas 2018. BPS. Jakarta. Bradshaw, S. D. et al. (2016) 'Family Functioning and Readiness in Family Recovery From Addiction', Journal of Groups in Addiction and Recovery, 11(1), p. pp.21-41. doi: 10.1080/1556035X.2015.1104644.

Çiftçi Demirci, A. et al. (2015) 'Sociodemographic characteristics and drug abuse patterns of adolescents admitted for substance use disorder treatment in Istanbul', The American Journal of Drug and Alcohol Abuse, 41(3), pp. 212-219. doi: $10.3109 / 00952990.2014 .973961$.

Dai, L. and Wang, L. (2015) 'Review of Family Functioning, Open Journal of Social Sciences, 03(12), pp. 134-141. doi: 10.4236/ jss.2015.312014.

Das, J. K. et al. (2016) 'Interventions for Adolescent Substance Abuse: An Overview of Systematic Reviews', Journal of Adolescent Health. Elsevier, 59(4), pp. 61-75. doi: 10.1016/j. jadohealth.2016.06.021.

Desiningrum, D. R., Suminar, D. R. and Surjaningrum, E. R. (2019) 'Psychological well-being among mothers of children with autism spectrum disorder: The role of family function', HUMANITAS: Indonesian Psychological Journal, 16(2), pp. 106-115. doi: 
dx.doi.org/10.26555/humanitas.v16i2.10981.

Farajzadegan, Z. et al. (2013) 'The relationship between family function and women's well-being., Iranian journal of nursing and midwifery research, 18(1), pp. 9-13.

Freitas, L. M. F. de and Souza, D. P. O. de (2020) 'Prevalence of drug use and family relationships among school adolescents in Cuiabá, MT, Brazil: a cross-sectional study, 2015.' Epidemiologia e servicos de saude, 29(1), p. e2019118. doi: 10.5123/s167949742020000100020.

Griffith, A. D. D. and Jackman, M. (2019) 'Peers or Parents?: An Examination of Risk and Protective Factors Influencing Use of and CuriosityaboutMarijuanaamong Adolescents in the Caribbean Island of Barbados', Journal of Child \& Adolescent Substance Abuse. Taylor \& Francis, 28(5), pp. 355-362. doi: 10.1080/1067828X.2020.1763884.

Gustiani, Y. and Ungsianik, T. (2016) 'Gambaran Fungsi Afektif Keluarga dan Perilaku Seksual Remaja, Jurnal Keperawatan Indonesia. Faculty of Nursing Universitas Indonesia, 19(No 2), pp. 85-91. doi: $10.7454 /$ jki. v19i2.459.

Hanifah, A. and Unayah, N. (2011) 'Mencegah Dan Menanggulangi Penyalahgunaan NAPZA Melalui Peran Serta Masyarakat', Sosio Informa, 16(1). doi: 10.33007/inf.v16i1.42.

Herawati, T. and Endah, N. Y. (2016) 'The Effect of Family Function and Conflict on Family Subjective Well-being with Migrant Husband, Journal of Family Sciences, 1(2 SEArticles), pp. 1-12. doi: 10.29244/jfs.1.2.1-12.

Indrawati, E. and Rahimi, S. (2019) 'Fungsi Keluarga Dan Self Control Terhadap Kenakalan Remaja, IKRA-ITH HUMANIORA: Jurnal Sosial dan Humaniora, 3(2), pp. 86-93.

Khan, M. R. et al. (2014) 'Gender and racial/ethnic differences in patterns of adolescent alcohol use and associations with adolescent and adult illicit drug use.', The American journal of drug and alcohol abuse. England, 40(3), pp. 213224. doi: 10.3109/00952990.2014.892950.

Kulla, T., Rumapea, P. and Tampongangoy, D. (2018) 'Kualitas Sumber Daya Manusia Dalam Meningkatkan Pembangunan Desa Tinggilbet Distrilk Beoga Kabupaten Puncak Provinsi Papua', JURNAL ADMINISTRASI PUBLIK. Sam Ratulangi University, 4(58).

Kusumastuti, H. and Hadjam, M. N. R. (2017) 'Dinamika Kontrol Sosial Keluarga dan Teman Sebaya pada Remaja Berisiko Penyalahgunaan NAPZA', Gadjah Mada Journal of Psychology (GamaJoP), 3(2), pp.
70-85. doi: 10.22146/gamajop.43439.

Mak, Y. W., Leung, D. and Loke, A. Y. (2019) 'The vulnerability to alcohol, tobacco, and drug use of adolescents in Hong Kong: a phenomenological study', BMC Pediatrics. BMC, 19(1), pp. 1-12. doi: 10.1186/s12887019-1678-1.

Mametja, M. and Ross, E. (2020) 'Decriminalized, Not Legalized: A Pilot Study of South African University Students' Views on the Use, Impact, Legalization and Decriminalization of Marijuana', Journal of Drug Issues. SAGE Publications Inc, 50(4), pp. 490-506. doi: $10.1177 / 0022042620931480$.

Nagarkoti, V., ShakuntlaPunia and Poonam (2014) 'Status of Family Functioning of Adolescents in Diverse Ecological Regions', Studies on Home and Community Science. Routledge, 8(2-3), pp. 81-87. doi: 10.1080/09737189.2014.11885421.

Nasution, S. L. et al. (2019) 'Pengaruh Pengetahuan Remaja tentang NAPZA dan HIV serta Pengetahuan Orang Tua tentang Program Pembangunan Keluarga terhadap Perilaku Penggunaan NAPZA pada Remaja, Jurnal Ilmu Keluarga \& Konsumen. Department of Family and Consumer Sciences, 12(2), pp. 100-113. doi: 10.24156/jikk.2019.12.2.100.

Nur'artavia, M. R. (2017) 'Karakteristik Pelajar Penyalahguna Napza Dan Jenis Napza Yang Digunakan di Kota Surabaya, The Indonesian Journal of Public Health, 12(1), pp. 27-38. doi: 10.20473/ijph.v12i1.2017.27-38.

Oroian, R.-F., Nemeş, B. and Cozman, D. (2018) 'Risk and resilience factors for adolescent drug use in Romania., Psihiatru.ro, 54(3), pp. 22-25. doi: 10.26416/Psih.54.3.2018.1914.

Patterson, A. et al. (2020) 'Motives for Alcohol and Marijuana Use as Predictors of Use and Problem Use Among Young Adult College Students', Journal of Drug Issues. SAGE Publications Inc, 50(4), pp. 359-377. doi: $10.1177 / 0022042620917101$.

Putri, D. D. M. (2018) 'Disfungsi Keluarga Pada Remaja Korban Penyalahgunaan Narkoba di Badan Narkotika Nasional Provinsi Kalimantan Timur', eJournal Sosiatri/ Sosiologi, 6(1).

Rohmah, U. and Athfal, A. (2018) 'Pengembangan Karakter Pada Anak Usia Dini (AUD)', AL-ATHFAL: JURNAL PENDIDIKAN ANAK, 4(1), pp. 85-102. doi: 10.14421/alathfal.2018.41-06.

Sari, N. (2019) 'Tinjauan Yuridis terhadap Upaya Pelajar/Mahasiswa dalam Memperoleh Narkoba, Jurnal Penelitian Hukum De 
Jure, 19(1), pp. 121-136. doi: 10.30641/ dejure.2019.V19.121-136.

Shaluhiyah, Z. et al. (2020) 'Health Risk Behaviors: Smoking, Alcohol, Drugs, and Dating among Youths in Rural Central Java', Kesmas: Jurnal Kesehatan Masyarakat Nasional (National Public Health Journal), 15(1), pp. 17-23. doi: 10.21109/kesmas.v15i1.2864.

Shin, Y., Miller-Day, M. and Hecht, M. L. (2019) 'Differential Effects of Parental "drug talk" Styles and Family Communication Environments on Adolescent Substance Use', Health Communication. Routledge, 34(8), pp. 872-880. doi: $10.1080 / 10410236.2018 .1439268$.
Sholihah, Q. (2015) 'Efektivitas Program P4GN Terhadap Pencegahan Penyalahgunaan NAPZA', KEMAS: Jurnal Kesehatan Masyarakat, 10(2), pp. 153-159. doi: 10.15294/kemas.v10i2.3376.

UNODC (2018) Executive Summary Conclusions and Policy Implications: World Drug Report 2018.

Yuan, X., Zhuo, R. and Li, G. (2019) 'Migration patterns, family functioning, and life satisfaction among migrant children in China: A mediation model', Asian Journal of Social Psychology. John Wiley \& Sons, Ltd, 22(1), pp. 113-120. doi: 10.1111/ajsp.12345. 